\title{
Three New Anamorph of Ceramothyrium from Fallen Leaves in Vietnam
}

\author{
Le Thi Hoang Yen ${ }^{*}$, Yasuhisa Tsurumi², Duong Van Hop${ }^{1}$, Katsuhiko Ando² \\ ${ }^{1}$ Institute of Microbiology and Biotechnology, Vietnam National University, Ha Noi, Vietnam \\ ${ }^{2}$ National Institute of Technology and Evaluation, Kisarazu, Japan \\ Email: ^yenlth@vnu.edu.vn, *yenlthvtcc@gmail.com
}

How to cite this paper: Yen, L.T.H., Tsurumi, Y., Hop, D.V. and Ando, K. (2018) Three New Anamorph of Ceramothyrium from Fallen Leaves in Vietnam. Advances in Microbiology, 8, 314-323. https://doi.org/10.4236/aim.2018.84021

Received: January 22, 2018

Accepted: April 23, 2018

Published: April 30, 2018

Copyright (c) 2018 by authors and Scientific Research Publishing Inc. This work is licensed under the Creative Commons Attribution International License (CC BY 4.0).

http://creativecommons.org/licenses/by/4.0/

\begin{abstract}
Three new anamorph of Ceramothyrium aquaticum sp. nov., Ceramothyrium exiguum sp. nov., and Ceramothyrium phuquocense sp. nov. are described and illustrated. These fungi were isolated from submerged decaying leaves collected from Phu Quoc National Park, Phu Quoc province, Viet Nam. The phylogeny based on ITS region and D1/D2 of the $28 \mathrm{~S}$ rDNA gene showed that these fungi nested in the Ceramothyrium. Morphologically, $C$. aquaticum, $C$. phuquocense sp. nov. and $C$. exiguum sp. nov. are characterized; they were different from known anamorph species of Ceramothyrium by having one main axis and two lateral arms with $70-90,33.5-72.5$ and $70-130 \mu \mathrm{m}$ long main axis, respectively. The table to compare Ceramothyrium anamorph is also given.
\end{abstract}

\section{Keywords}

Aquatic Fungi, Annamorph, Telemorph, Litter Fungi

\section{Introduction}

The genus Ceramothyrium was erected by Bat. \& Maia based on type species Ceramothyrium paiveae, it was characterized by the lack of setae and by the hyaline, transversely pluriseptate ascospores [1]. No anamorph stage of this fungus was discovered until the study of [2]. In this study, they reported Stanhughesia as anamorph of the Ceramothyrium. There were 38 species of Ceramothyrium were reported; among them, three species $C$. carniolicum, C. linnaeae and C. lycopodii had Stanhughesia asexual stage [2]. More two anamorph of Ceramothyrium were reported under the older telemorph name: $C$. melastoma and C. podocarpi. While C. melastoma has Trisulcosporium morph, C. podocarpi has its own anamorph stage [3]. 
During an investigation of microfungi in Vietnam, three anamorh of Ceramothyrium were isolated from fallen leaves which were collected in Phu Quoc National Park of Vietnam. Conidia of these fungi produced when they were submerged in distill water after $2-3$ days. They have tri-radiate spores, consisted chains of sausage-shaped cells, one main axis and (one)-two arms at the basal cell. Phylogeny of these fungi based on nrDNA large subunit (LSU D1/D2) and ITS region showed that these fungi belong to Ceramothyrium. They are differed from each other in the celled-numbers and the lengths of each cell.

The purposes of this study is to characterize these fungi not only morphologically but also phylogenetically and as well as to describe and illustrate two new anamorph of Ceramothyrium: C. aquaticum sp. nov., C. phuquocense sp. nov. and $C$. exiguum sp. nov.

\section{Materials and Methods}

\subsection{Isolation and Morphological Identification}

Fallen leaves were collected in Phu Quoc National Park of Viet Nam in 2011. The samples were kept in moist chamber for 3 - 10 days in a laboratory; leaf was cut in to pieces, $1-1.5 \times 3-3.5 \mathrm{~cm}$, and spread on surface of a low nutrient carbon agar medium (LCA) [4]. A single spore on the LCA was isolated by a Skerman's micromanipulator under a light microscope to obtain the pure culture. Cultures have been deposited to the Vietnam Type Culture Collection, Institute of Microbiology and Biotechnology, Vietnam National University, Ha Noi, Vietnam (VTCC) and to the National Institute of Technology and Evaluation, Biological Resources Center, Chiba, Japan (NBRC).

\subsection{Morphological Study}

The isolates were cultured at $25^{\circ} \mathrm{C}$ on a potato carrot agar medium (PCA, extract from $20 \mathrm{~g} / \mathrm{L}$ potato, extract from $20 \mathrm{~g} / \mathrm{L}$ carrot, $15 \mathrm{~g} / \mathrm{L}$ agar), $\mathrm{LCA}$ and potato dextrose agar (PDA, Nissui, Japan) for morphological observations. Observations were made under a differential interference contrast microscope (DIC: Axioplan 2, Zeiss, Jena, Germany) and a scanning electron microscope (JSM-6060: JEOL, Tokyo, Japan).

\subsection{DNA Isolation and PCR Amplification}

A Small pieces of a colony $(3 \times 3 \mathrm{~mm})$ grown on malt extract agar (MEA) medium at $25^{\circ} \mathrm{C}$ for $10 \mathrm{~d}$ were put into $2 \mathrm{~mL}$ Cryo tubes. DNA was extracted using the PrepMan ${ }^{\mathrm{Tm}}$ Ultra Sample Preparation Reagent (Applied Biosystems, Foster City, CA, USA). PCR was performed by using KOD-Plus Kit (Toyobo, Osaka, Japan), following the manufacturer's protocol. The nrDNA large subunit region (LSU D1/D2) was amplified with primers NL1 and NL4 [5]. To amply the ITS region, the combination ITS1 and ITS4 [6] were used. Amplification of the DNA fragments was performed using the GeneAmp PCR System 9700 (Applied Biosystems) under the following thermal cycling programme: an initial 
denaturation at $94^{\circ} \mathrm{C}$ for $2 \mathrm{~min}, 35$ cycles of denaturation at $94^{\circ} \mathrm{C}$ for $15 \mathrm{~s}$, annealing at $56^{\circ} \mathrm{C}$ for $30 \mathrm{~s}$, extension at $68^{\circ} \mathrm{C}$ for $1 \mathrm{~min} 30 \mathrm{~s}$, a final extension at $68^{\circ} \mathrm{C}$ for $10 \mathrm{~min}$, and a $16^{\circ} \mathrm{C}$ soak. PCR products were checked by agarose gel electrophoresis, and were purified by using AMPureKit (Agencourt Biosciences, Beverly, MA, USA). Sequencing reactions were performed by using the Big Dye Terminator V3.1 Cycle Sequencing Kit (Applied Biosystems) and the primers of the PCR. The newly generated sequence data were deposited in GenBank.

\subsection{Phylogenetic Analysis}

Sequences were assembled and edited manually using BioEdit ver. 7.09 (Tom Hall, Ibis Biosciences, Carlsbad, CA, USA). Sequences were aligned with GenBank sequence data obtained from the NCBI database

(http://www.ncbi.nlm.nih.gov/) by using Clustal X [7]. A phylogenetic tree was inferred with neighbor-joining (NJ) method [8] and the Knuc value [9] by using Clustal X. The topology of the tree was evaluated by the bootstrap resembling method [10] with 1000 replicates. The NJplot programme [11] was used for plotting the phylogenetic tree.

\section{Results}

\subsection{Morphology}

All of three fungal isolates were slow growth on LCA and PDA media, spores are easily produced when submerging in water 3 - 4 days. Conidiopphores absent. Conidiogenous cells intercalary in hyphae. Conidia in cultures are holoblastic, tri-radiate. The spore arises from a cell of the mycelium as a lateral bud. This bud is initially unicellular and constricted where it joints the parent hypha, it grows into the main axis of the spore. When the main axis reaches to three- or four-celled, one or two lateral arms are budding out from opposite side of basal cell of the main axis. At first arms are unicellular, and then it extend away from the main axis at near $120^{\circ}$ until to become three- to six-celled as the main axis itself extends farther to become eight- to ten-celled. Eventually the main axis becomes constricted off from the parent cell and the spore become detached.

\subsection{Phylogenetic Analysis}

In a BLAST search using the blast from the National Center for Biotechnology Information (NCBI) [12], VTCCF-1206 (LC360294); VTCCF-1209 (LC360295); VTCCF-1210 (LC360296) had 96.68\%; 95.23\%; 97.03\% similarity to the partial rRNA LSU gene sequences of Ceramothyrium carniolicum (FJ358232), an Chaetothyriales fungus, respectively. The LSU region of the sequences was used to obtain additional sequences from Gen-Bank, which was added to the alignment. The manually adjusted LSU alignment contained 34 sequences (including the one out group sequence). In NJ analysis, the phylogenetic hypothesis highly supports three monophyletic groups, Capnodiaceae (Verrucariaceae (Verruca- 
riales) and Herpotrichiellaceae, Trichomeriaceae, Cyphellophoraceae, and Chaetothyriaceae (Chaetothyriales). The sequences of the three newly isolated fungi cluster within the Chaetothyriaceae clade with $75 \%$ boostrap value, the clad contains: Ceramothyrium carniolicum, C. ficus, C. thailandicum, C. podocarpi, C. longivolcaniforme, Cyphellophora laciniata, C. eugeniae, C. sesilis (Figure 1).

The aligned ITS region sequences of approximately 600 bases were obtained from isolates were aligned with the ITS region of the sequences obtained from Gen-Bank. The manually adjusted ITS alignment contained 21 sequences (including the one out group sequence). In NJ analysis, the phylogenetic hypothesis showed that VTCCF-1206 (LC360297); VTCCF-1209 (LC360298) and VTCCF-1210 (LC360299) cluster within the Ceramothyrium carniolicum clad, with bootstrap support of $98 \%$ (Figure 2).

\subsection{Taxonomy}

Ceramothyrium aquaticum VTCCF-1210 Yen L.T.H, Ando K. and Tsurumi Y. (Figure 3(c), Figure 4(b), Figure 4(f)).

$$
\text { MycoBank no.: MB824817 }
$$

Colonies on LCA and PDA are dark brown, plane, $10-15 \mathrm{~mm}$ in diameter after 7 days at $25^{\circ} \mathrm{C}$. Mycelium was pigmented, $2-2.5 \mu \mathrm{m}$. Conidia are sporulated easily after 3 - 4 days aerated. Conidiopphores absent. Conidiogenous cells intercalary in hyphae. Conidia in culture are holoblastic, pale olivaceous, tri-radiate, they consist of a multi-septa main axis and two arms, which are much constricted at the middle cell and the septa. Main axis usually extends six- to eight-celled, usually $70-90 \mu \mathrm{m}$ long (some time reaches to $100 \mu \mathrm{m}$ ) $\times 2.3-2.7 \mu \mathrm{m}$ wide. From the basal cell of the main axis, two arms arise. The arms are shorter than the main axis, (3) - $5-6$ septa, (30) $-50-70 \mu \mathrm{m} \times 2.5-2.7 \mu \mathrm{m}$.

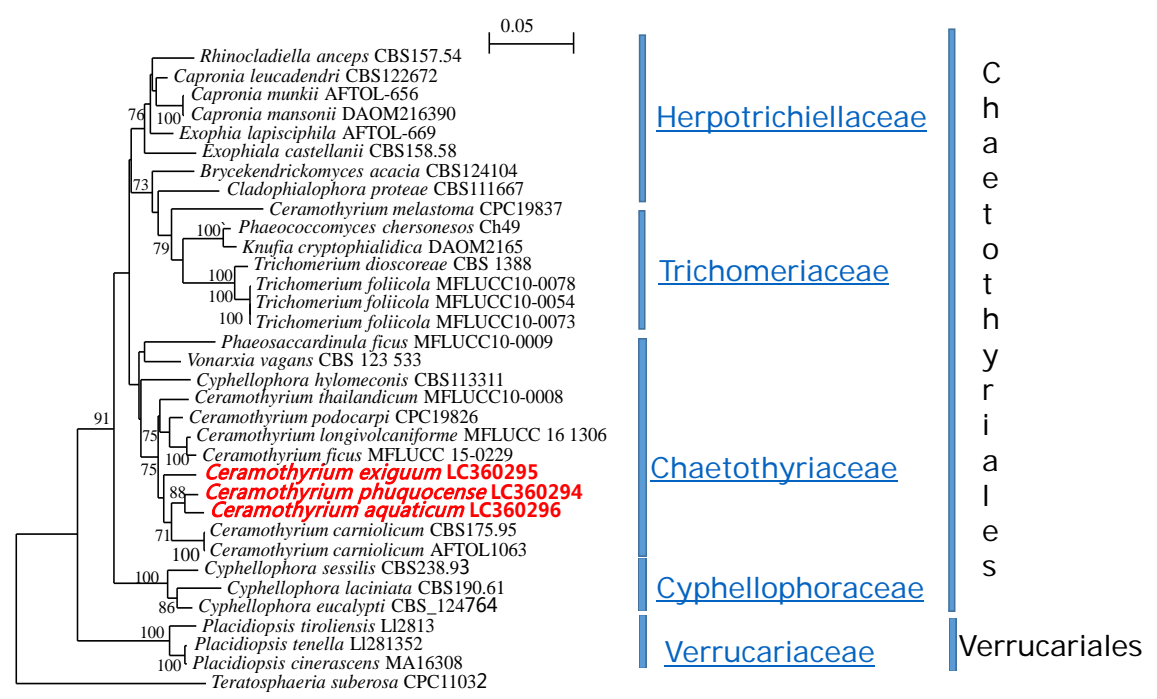

Figure 1. Phylogeny of Stanhughesia spp. and their relative species base on 28S D1D2 rDNA sequence. MP bootstrap value $\geq 70 \%$. 


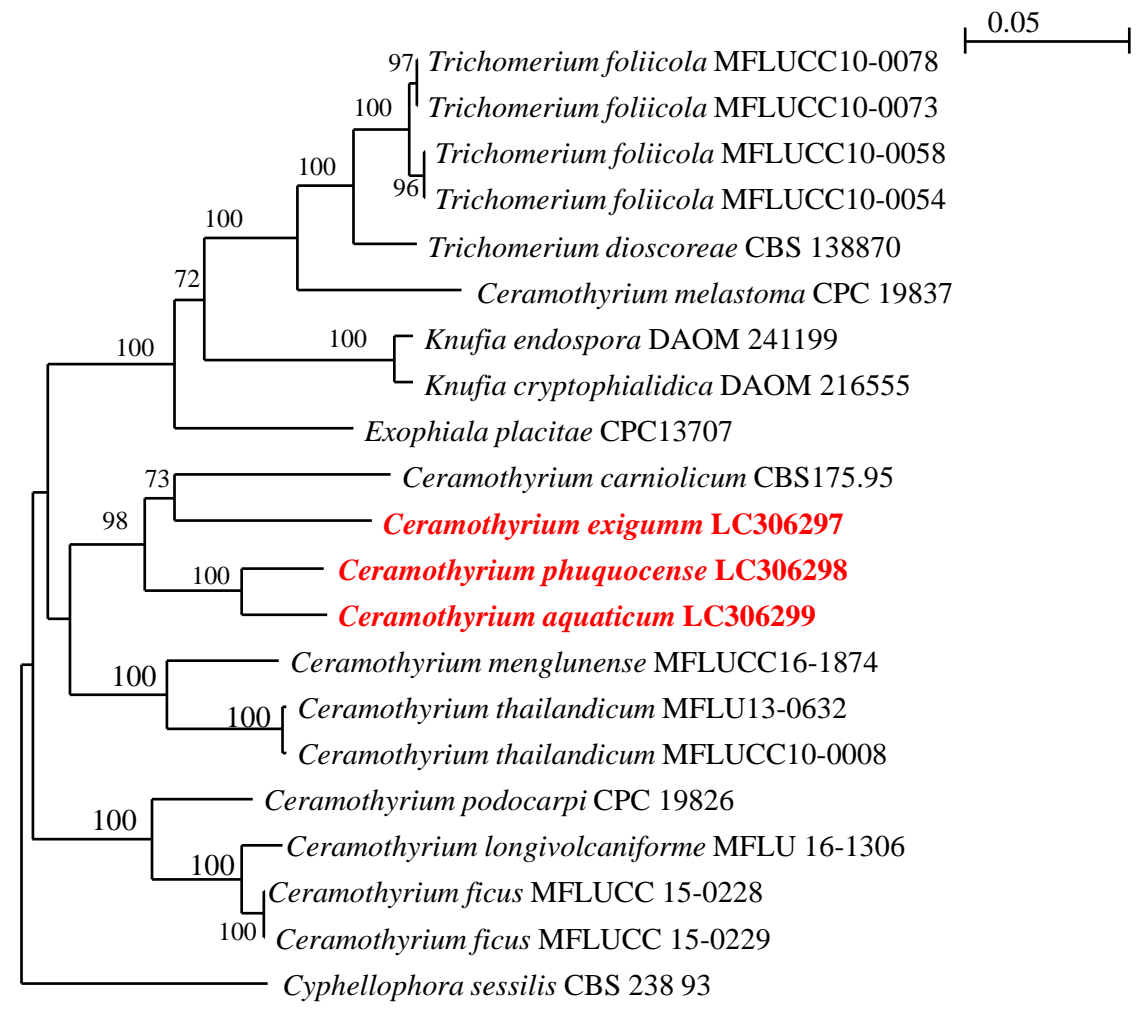

Figure 2. Phylogeny of Stanhughesia spp. and their relative species base on ITS rDNA sequence. MP bootstrap value $\geq 75 \%$.

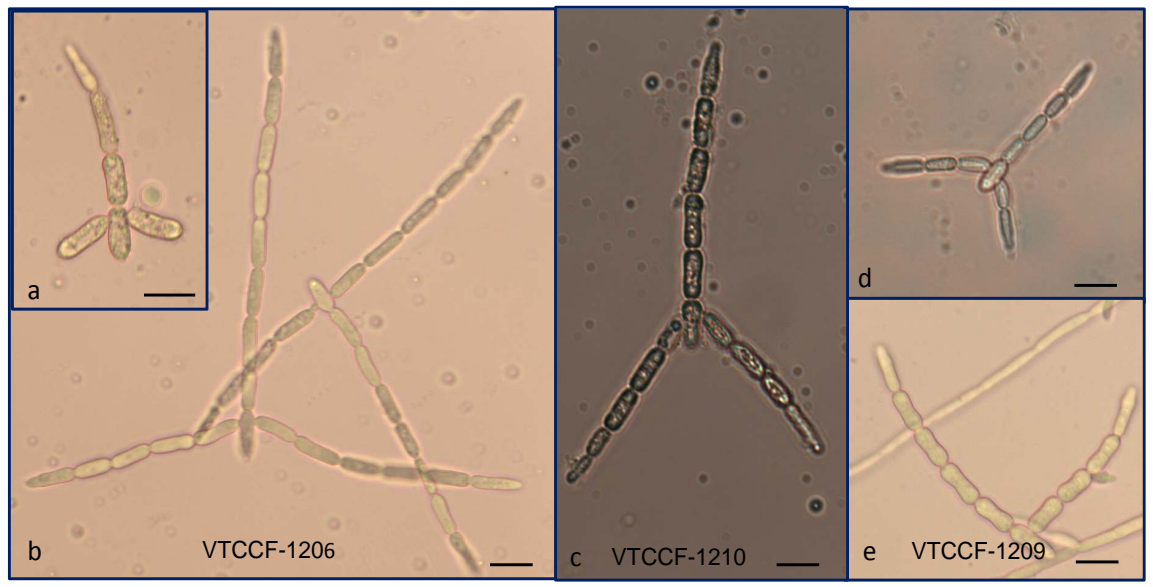

Figure 3. Morphology of Ceramothyrium under microscopic: (a) Young conidium of $C$. phuquocense; (b) mature conidium of $C$. phuquocense; (c) mature conidium of $C$. aquaticum; (d) mature conidium with 2 arm of C. exiguum; (e) detach conidium of $C$. exiguum, bar $=10 \mu$.

Habitat: isolated from fallen leaves of unidentified deciduous broad-leaved tree, Phu Quoc National Park, Kien Giang Prov., Vietnam, Nov. 2011, collected by L.T.H Yen. Culture is deposited in the Vietnam Type Culture Collection, Hanoi and National Institute of Technology and Evaluation-Japan (VTCC-1210 = NBRC 111199) VTCC-F-EH-1210 


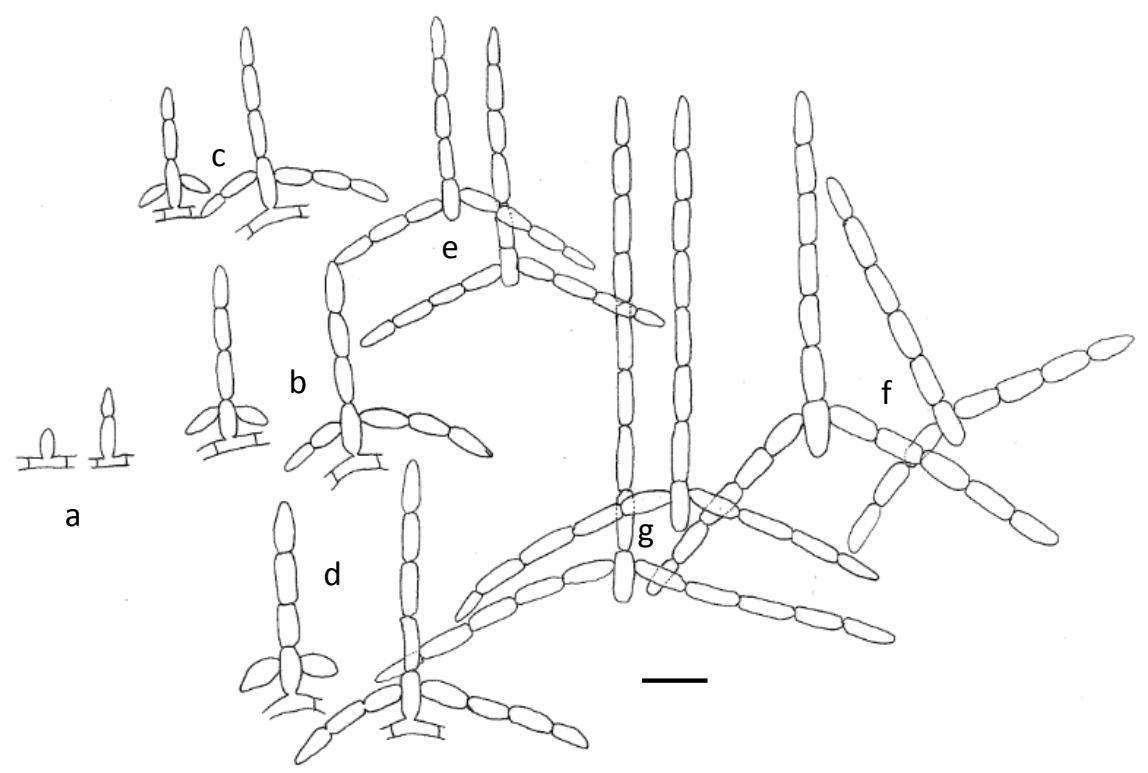

Figure 4. The conidia autogeny of Ceramothyrium: a. main axis start budding out from hyphae; (b)-(d) development of the main axis and two lateral arms; (b) Ceramothyrium phuquocense; (c) Ceramothyrium exiguum; (d) Ceramothyrium aquaticum; (e)-(g) mature conidia; (e), Ceramothyrium exiguum; (f) Ceramothyrium aquaticum; (g) Ceramothyrium phuquocense, bar $=10 \mu$.

Ceramothyrium exiguum L.T.H. Yen, K. Ando and Tsurumi sp. nov. VTCCF-1209 (NBRC 111198) (Figure 3(e), Figure 4(c), Figure 4(e)).

MycoBank no.: MB824818

Colonies are dark brown, plane on LCA; dark grey, twisted in PDA medium, slow growth, $10-15 \mathrm{~mm}$ in diameter after 7 days at $25^{\circ} \mathrm{C}$. Mycelium was pigmented, 2 - $2.5 \mu \mathrm{m}$. Conidia are sporulated easily after $3-4$ days aerated. Conidiophores absent. Conidiogenous cells intercalary in hyphae. Conidia in culture are holoblastic, pigmented, tri-radiate, they consist of a multi-septa main axis and two arms, which are much constricted at the septa. Main axis usually extends to five-celled, sometimes up to six-celled, $50-70 \times 2.0-2.5 \mu \mathrm{m}$ with each cell $10-12 \mu \mathrm{m}$ long. From the basal cell of the main axis, (one) - two arms arise. The arms are shorter than the main axis, 3 - 4 septa, $25-50 \mu \mathrm{m} \times 2.0-2.5 \mu \mathrm{m}$ with each cell 9 - $11 \mu \mathrm{m}$ long.

Type: VTCC-F-H-1209 (holotype: dried culture specimen, from VTCCF1209, on LCA) deposited in the Vietnam Type Culture Collection, Hanoi (VTCC). NBRC H-13275 (isotype: dried culture specimen, from VTCCF-1209, on LCA) deposited in the NITE Biological Resource Center (NBRC).

Ex-type culture: VTCCF-1209 (=NBRC 111198), isolated from fallen leaves of unidentified deciduous broad-leaved tree, Phu Quoc National Park, Kien Giang Prov., Vietnam, Nov. 2011, collected by L.T.H Yen.

Ceramothyrium phuquocense L.T.H. Yen, K. Ando and Tsurumi sp. nov. VTCCF-1206 (NBRC111197) Figure 3(a), Figure 3(b); Figure 4(d), Figure 4 (g). 
MycoBank no.: MB424823

Colonies are dark grey on LCA and PDA media. The mycelium was dark to brown, submerged in agar, twisted together, little aerial mycelium was produced, the colony became convoluted. Twisted mycelia form a restricted colony that makes it difficult to prepare a good permanent slide. Conidia are not produce on the media, after submerging in water 3 - 4 days, they were sporulated easily. Conidiophores absent. Conidiogenous cells intercalary in hyphae. Conidia in culture are holoblastic, pale olivaceous, tri-radiate, consist of a main axis and two arms. Cells of main axis and arms constricted at intervals so that they look like chains of sausages. Main axis extends up to ten-celled, (80) - $95-125 \times 2.5$ $2.7 \mu \mathrm{m}$ with each cell $12-14 \mu \mathrm{m}$ long. From the basal cell of the main axis, two arms arise. The arms are shorter than the main axis, (3) - 5 - 6 - (7) septa, (30) $50-80 \mu \mathrm{m} \times 2.5-2.7 \mu \mathrm{m}$.

Type: VTCCF VTCC-F-H-1206 (holotype: dried culture specimen, from VTCCF-H-1206, on LCA) deposited in the Vietnam Type Culture Collection, Hanoi (VTCC). NBRC H-13274 (isotype: dried culture specimen, from VTCCF-H-1206, on $\underline{\underline{\text { LCA) }}}$ deposited in the NITE Biological Resource Center (NBRC).

Ex-type culture: VTCCF-1206 (= NBRC 111197), isolated from fallen leaves of unidentified deciduous broad-leaved tree, Phu Quoc National Park, Kien Giang Prov., Vietnam, Nov. 2011, collected by L.T.H Yen.

\section{Discussion}

All of three newly Ceramothyrium anamorphs are agree well with Trisulcosporium acerium Hudson and Sutton 1964 [13] on the autogeny, morphology and the habitate. They have tri-radiate or tetra-radiate spores which consisted a main axis and two to three arms. Cells of main axis and arms constricted at intervals so that they look like chains of sausages. The main axis is tapering slightly to the apex while two arms arise equidistantly from the basal cell of the main axis. Furthermore, both Trisulcosporium and our newly Ceramothyrium anamorph were isolated from fallen leaves and their spore production was induced by water. But there were some differences between Ceramothyrium anamorph and Trisulcosporium: Arms of Hudson and Sutton's fungus were budding out from the lower portion of basal cell, whereas, in our Vietnamese fungus the arms were budding out from upper part of the basal cell. Moreover, Trisulcosporium had hialyne conidia, while in Ceramothyrium aquaticum, $C$. minima and $C$. phuquocense, the conidia were pigmented. These characteristics make our fungi different from Trisulcosporium.

Morphologically, our fungi are similar to some known Ceramothyrium anamorph: Stanhughesia carniolica, S. linnaeae [2] and the Trisulcosorium anamorph stage of Ceramothyrium melastoma [3] by having tri-radiate/tetra-radiate, pigmented spore which consist of one main axis and one-two arms arising at the basal cell. However, there are some different points: $S$. carniolica, $S$. linnaeae and 
C. melastoma had a truncate basal cell, 3-5 $\mu \mathrm{m}$ wide, subsequent ones gradually tapered to a $2-3 \mu \mathrm{m}$ wide, apical cell ending in a c. $1-1.5 \mu \mathrm{m}$ wide beak, thinand smooth-walled, markedly constricted at the main septa, but slightly or not constricted at secondary, very thin septa which sometimes divide the cells. While our Ceramothyrium anamorph, septa is constricted at all cells, makes the main axis and arms look like chains of sausages. Furthermore, size of main axes of our new Ceramothyrium differs from each other and all of other known Ceramothyrium anamorph. Main axes of Ceramothyrium aquaticum, C. minima and $C$. phuquocense are 70 - 90, $33.5-72.5$ and $70-130 \mu \mathrm{m}$, respectively; while Stanhughesia carniolica, S. linnaeae and C. melastoma's main axes were 70 - 120, 25 - 40 and $15-30 \mu \mathrm{m}$, respectively (Table 1).

Table 1. Comparison of conidium morphology in the Ceramothyrium anamorph species.

\begin{tabular}{|c|c|c|c|c|c|}
\hline \multirow{3}{*}{ Species } & \multicolumn{4}{|c|}{ Length conidia $(\mu \mathrm{m})$} & \multirow{3}{*}{ Refference } \\
\hline & \multicolumn{4}{|c|}{ (Numbers of cell/ conidia) } & \\
\hline & $\begin{array}{l}\text { Main axis } \\
\text { (No of cell) }\end{array}$ & $\begin{array}{c}\text { Branch } 1 \\
\text { (No of cell) }\end{array}$ & $\begin{array}{c}\text { Branch } 2 \\
\text { (No of cell) }\end{array}$ & Wide of conidia & \\
\hline $\begin{array}{c}\text { Stanhughesia } \\
\text { carniolica }\end{array}$ & $\begin{array}{l}70-120 \\
6-10\end{array}$ & $\begin{array}{l}\text { to } 60 \\
\text { (to } 4 \text { ) }\end{array}$ & ND & \multirow{2}{*}{$\begin{array}{c}3-4 \mu \mathrm{m} \text { wide at } \\
\text { the basal cell, } \\
\text { gradually tapered } \\
\text { to a }(1)-2-2.5 \mu \mathrm{m}\end{array}$} & O. Const. 1989 \\
\hline $\begin{array}{c}\text { Stanhughesia } \\
\text { linnaeae }\end{array}$ & $\begin{array}{c}25-40 \\
3-6\end{array}$ & $\begin{array}{c}13-30 \\
2-3\end{array}$ & $\begin{array}{c}13-30 \\
2-3\end{array}$ & & O. Const. 1989 \\
\hline $\begin{array}{c}\text { Stanhughesia } \\
\text { lycopodii }\end{array}$ & $\begin{array}{l}25-45 \\
(4-6)\end{array}$ & $\begin{array}{c}15-30 \\
2-4\end{array}$ & \multicolumn{2}{|r|}{ at apex cell. } & O. Const. 1989 \\
\hline $\begin{array}{c}\text { Stanhughesia } \\
\text { nipponica }\end{array}$ & $\begin{array}{l}32-40 \\
(3-4)\end{array}$ & $10-17$ & $10-17$ & $\begin{array}{l}2-2.5 \mu \mathrm{m} \text { wide at } \\
\text { the basal cell, } \\
\text { gradually tapered } \\
\text { to a } 1-1.5 \mu \mathrm{m}\end{array}$ & $\begin{array}{l}\text { K. Matsush. \& } \\
\text { Matshu. } 1996\end{array}$ \\
\hline \multicolumn{6}{|l|}{$\begin{array}{c}\text { Ceramothyrium } \\
\text { melastoma }\end{array}$} \\
\hline $\begin{array}{c}\text { Stanhughesia } \\
\text { morph }\end{array}$ & $40-60$ & $7-25$ & ND & $2.5-3.0 \mu \mathrm{m}$ & $\begin{array}{l}\text { Crous et al. } \\
2012\end{array}$ \\
\hline $\begin{array}{c}\text { Trisulcosporium } \\
\text { morph }\end{array}$ & $15-30$ & $15-35$ & $15-35$ & $(2.5)-3-4 \mu \mathrm{m}$ & \\
\hline $\begin{array}{l}\text { Ceramothyrium } \\
\text { podocarpi }\end{array}$ & \multicolumn{3}{|c|}{$\begin{array}{c}\text { Star - shaped conidium } \\
\text { with numerous branches, } \\
25 \text { - } 90 \mu \mathrm{m} \text { long, } 1 \text { - } 9 \text { - septate, }\end{array}$} & $\begin{array}{c}4-6 \mu \mathrm{m} \text { wide with } \\
\text { hilum } 1.5-2 \mu \mathrm{m} \\
\text { diam }\end{array}$ & $\begin{array}{l}\text { Crous et al. } \\
\quad 2012\end{array}$ \\
\hline $\begin{array}{c}\text { Ceramothyrium } \\
\text { acerinum }\end{array}$ & $\begin{array}{c}70-130.3 \\
(6-11)\end{array}$ & $\begin{array}{c}(0)-43-85.9 \\
(0)-(4-7)\end{array}$ & $\begin{array}{c}(0)-40.8-93.5 \\
((0)-4-7)\end{array}$ & $2.3-2.7$ & This study \\
\hline $\begin{array}{c}\text { Ceramothyrium } \\
\text { exiguum }\end{array}$ & $\begin{array}{c}37.3-72.5 \\
(3-6)\end{array}$ & $\begin{array}{c}(0)-19.3-44.3 \\
(0)-2-4\end{array}$ & $\begin{array}{c}\text { (0) } 25.8-54.3 \\
((0) 3-4)\end{array}$ & $2.3-2.5$ & This study \\
\hline $\begin{array}{c}\text { Ceramothyrium } \\
\text { phuquocense }\end{array}$ & $\begin{array}{l}67-95 \\
(6-8)\end{array}$ & $\begin{array}{l}(0)-3-70 \\
(0)-3-6\end{array}$ & $\begin{array}{l}(0)-45-60 \\
((0)-3-5)\end{array}$ & $2.5-2.7$ & This study \\
\hline
\end{tabular}


The genus Ceramothyrium has Stanhughesia asexual morphs [2] [3] and Trisulcosporium [3] represents a genus of epiphyllous ascomycetes in the Chaetothyriales for which DNA data has been lacking until the recent study of Chomnunti et al. (2012), Crous et al. (2102), Hongsanan et al. (2015) and Zeng et al. (2016) [3], [14], [15] and [16]. Phylogeny based on ITS region and D1/D2 of the $28 \mathrm{~S}$ rDNA gene analysis showed that these new Ceramothyrium anamorph were nested in Ceramothyrium clad with $98 \%$ and $75 \%$ bootstrap value, respectively. In this study, only the asexual morph of Ceramothyrium aquaticum, C. minima and $C$. phuquocense were observed, we choose to name it in the older sexual genus, Ceramothyrium which consisted of 41 taxa, accepting Stanhughesia carniolica, S. linnaeae, S. lycopodii, S. nipponica, C. melastoma, C. podocarpi [2], [3], [17] and our three new anamorph having existing names in Ceramothyrium as synonym.

\section{Acknowledgements}

This work was conducted under the Joint Research Project on "Taxonomic and ecological studies of microorganisms in Viet Nam and the utilization" between Biological Resource Center, National Institute of Technology and Evaluation, Japan and Institute of Microbiology and Biotechnology, Viet Nam National University and the project "Reservation of Microorganism Genom" funded by the Ministry of Science and Technology, Vietnam. We also thank to the QG16-35 project from VNU. We thank Mr. Kamijo T-NITE for his kindly doing the sequences in this study.

\section{References}

[1] Batista, A.C. and Maia, H.S. (1957) Ceramothyrium a New Genus of the Family Phaeosaccardinulaceae. Atti dell Istituto Botanico della Università e Laboratorio Crittogamico di Pavia, 14, 23-52

[2] Constantinescu, O., Holm, K. and Holm, L. (1989) Teleomorph-Anamorph Connections in Ascomycetes. 1-3. Stanhughesia (Hyphomycetes) New Genus, the Anamorph of Ceramothyrium. Studies in Mycology, 31, 69-84.

[3] Crous, P.W., Shivas, R.G., Wingfiel, M.J., et al. (2012) Fungal Planet Description Sheets: 128-153. Persoonia, 29, 146-201. https://doi.org/10.3767/003158512X661589

[4] Miura, K. and Kudo, M.Y. (1970) An Agar-Medium for Aquatic Hyphomycetes (in Japanese). Transactions of the Mycological Society of Japan, 11, 116-118.

[5] O’Donnell, K. (1993) Fusarium and Its Near Relatives. In: Reynolds, D.R., Taylor, J.W., Eds., The Fungal Holomorph: Mitotic, Meiotic and Pleomorphic Speciation in Fungal Systematics, CABI, Wallingford, 225-233.

[6] White, T.J., Bruns, T., Lee, S. and Taylor, J. (1990) Amplication and Direct Sequencing of Fungal Ribosomal RNA Genes for Phylogenetics. In: Innis, M.A., Gelfand, D.H., Sninsky, J.J., White, T.J., Eds. PCR Protocols. A Guid to Methods and Applications, Academic Press, San Diego, Canifornia, 315-322.

[7] Thompson, J.D., Gibson, T.J., Plewniak, F., Jeanmougin, F. and Higgins, D.G. (1997) The CLUSTAL X Windows Interface: Flexible Strategies for Multiple Sequence Alignment Aided by Quality Analysis Tools. Nucleic Acids Research, 24, 
4876-4882. https://doi.org/10.1093/nar/25.24.4876

[8] Saitou, N. and Nei, M. (1987) The Neighbor Joining Method: A New Method for Reconstructing Phylogenetic Tree. Molecular Biology and Evolution, 4, 406-425.

[9] Kimura, M. (1980) A Simple Method for Estimating Evolution Rates of Base Substitutions through Comparative Studies of Nucleotide Sequences. Journal of Molecular Evolution, 16, 111-120. https://doi.org/10.1007/BF01731581

[10] Felsenstein, J. (1985) Confidence Limits on Phylogenies: An Approach Using Bootstrap. Evolution, 39, 783-791. https://doi.org/10.1111/j.1558-5646.1985.tb00420.x

[11] Perrière, G. and Gouy, M. (1996) WWW-Query: An On-Line Retrieval System for Biological Sequence Banks. Biochimie, 78, 364-369. https://doi.org/10.1016/0300-9084(96)84768-7

[12] Altschul, S.F., et al. (1990) Basic Local Alignment Search Tool. Journal of Molecular Biology, 215, 403-410. https://doi.org/10.1016/S0022-2836(05)80360-2

[13] Hudson, H.J. and Sutton, B.C. (1964) Trisulcosporium and Tetranacrium, Two New Genera of Fungi Imperfecti. Transactions of the British Mycological Society, 47, 197-203. https://doi.org/10.1016/S0007-1536(64)80053-X

[14] Chomnunti, P., Ko-Ko, T.W., Chukeatirote, E., Hyde, K.D., Cai, L., et al. (2012) Phylogeny of the Chaetothyriaceae in Northern Thailand Including Three New Species. Mycologia, 103, 382-395. https://doi.org/10.3852/11-066

[15] Hongsanan, S., Hyde, K.V., et al. (2015) Fungal Biodiversity Profiles 11-20. Cryptogamie, Mycologie, 36, 355-380. https://doi.org/10.7872/crym/v36.iss3.2015.355

[16] Zeng, X.U., Wen, T.C., Chomnunti, P., Liu, J.K., Boonme, S. and Hyde, D.K. (2016) Ceramothyrium longivolcaniforme sp. nov., a New Species of Chaetothyriaceae from northern Thailand. Phytotaxa, 267, 51-60.

https://doi.org/10.11646/phytotaxa.267.1.5

[17] Matsushiam, K. (1996) Matsushima Mycological Memories 9. Author, Kobe. 